\title{
Development Model of Psycho-educative and Psycho-religious in Coping Deviant Behavior in Early Adolescence
}

\author{
Safuwan $^{1}$, Ella Suzanna ${ }^{1}$, Nursan Junita ${ }^{1}$, Liza Adyani $^{1}$, Muhammad Ali ${ }^{2}$ \\ \{safuwan@unimal.ac.id\} \\ ${ }^{1}$ Department of Psychology, Universitas Malikussaleh, Aceh, Indonesia \\ ${ }^{2}$ Department of Communication Science, Universitas Malikussaleh, Aceh, Indonesia
}

\begin{abstract}
This study aims to understand early adolescences parenting care models by parents in shaping psycho-educative and psycho-religious, by taking samples in North Aceh district, Aceh Province, Indonesia. The social reality of the last decade shows a wide range of behavioral changes among early adolescents that increasingly hit the world of education in general. Cases of bullying, sexual harassment, rape and drug abuse among teenagers have troubled parents, communities, child psychologists, educators and educational observers. This social fact in the cultural setting of Acehnese people in particular and Indonesia, in general, can be considered a shift of new behavioral values. The results of this study signal that families need to monitoring the progress of their children and need to focus on the care of psycho-educative and psycho-religious aspects, so that when children enter junior high school age and face the hustle and bustle of social reality, early adolescence is not rigid and able adjusting himself comprehensively with reference to his religious knowledge.
\end{abstract}

Keywords: Early adolescence, Parenting, Psycho-educative, and psycho-religious

\section{INTRODUCTION}

In the last decade, deviant behavior in adolescents such as; drug use, prostitution and criminality in various parts of Indonesia, including in Aceh spread drastically and craze. The latest data released by government agencies and non-government organization (NGo) is astonishing. The National Narcotics Agency (BNN) report 2014 mentions that nationally the projection and scenario of 2015 students who use drugs around 1,178,300 people. and will increase in 2016 to about 1,225,700 students. The projected increase in 2015 is around 211,900 . Then the increase in 2016 increases the projection to about 218,900 people. In addition to the abuse of narcotics and illegal drugs, juvenile delinquency is related to sex, pornography, andpornoaction. In 2014, Deputy for Family Planning and Reproductive Health (BKKBN) released the results of the survey, which is $46 \%$ aged 15-19 years have sex. National Census data even show 48 - 51 percent of pregnant women are teenagers. Furthermore, the National Commission for Child Protection also gave information about 
teenage deviant behavior that of 4,726 respondents $97 \%$ had ever watched pornography, and 93.7\% said they were not virgin. Even $21.26 \%$ admitted to having an abortion.

This condition is in contrast to the parenting process at home and also the teaching process of teachers in Indonesian schools. In general, parenting process and education process at school still put forward the application of moral values, the socio-cultural heritage of the nation. This is expressly mentioned in the Law of the Republic of Indonesia Number 20 Year 2003 on National Education System that the goal of national education of Republik of Indonesia to educate the life of the nation and develop humanity as a whole, that is man who believes and piety towards God Almighty and virtuous noble character, knowledge and skills, physical and mental health, a solid and independent personality and a sense of people and national responsibility.

\section{LITERATURE REVIEW}

\subsection{Parenting Contexts}

Education is practically oriented to a certain value to guide, teach and train students (children) so that the child can improve, develop and distribute all the potential of physical, spiritual, intellectual and lust, so the child can live more satisfied and good, productive and responsible morally in order to meet the needs of himself, his family and the broad community, nation and country, concluded Baihaqi [1], responded to the opinions of world education experts. Therefore, the parenting context is identical to educating the child to fit his or her desired expectations. The study of literature that the model of child care in various dimensions of life tends to pivot on modern thinking. For the most part, Indonesia's society and education system adopt modern parenting models. Yet the meaning of nurturing or educating children is not solely related to sending children to study science, but more broadly than that, namely to pay attention to mental-emotional, mental, intellectual, mental, social and mental-spiritual in the overall meaning that the child's growth will be complete. Parenting of child is generally understood as a parent or family way of educating their children. Educational views related to parenting as the behavior of parents to guide or teach children to be empowered cognitive, affective and conative aspects in a balanced and plenary. Parenting is a conscious effort made by parents to form the child's personality [2].

Daradjat [3], raising a child means educating and nurturing the child, taking care of his food, drink, clothing, and success in the first period until adulthood. Shochib (2010), explained in the pattern of parenting is known there are two dimensions of behavior that is directive behavior and supportive behavior, involving direct communication where parents describe the role of children and tell the child what they should do, where, when, and how to do a task. The second parenting style involves two-way communication where the parent listens to the child, encourages, encourages, poses positive strikes and helps to direct the child's behavior. A self-disciplined child has self-organization based on religious values, cultural values, societal rules, life-views, and meaningful life attitudes for himself, society, nation, and state. Indira [4] mentions several criteria of loving parenting so that it is considered this parenting pattern, effective in coaching the child's personality, between;

\section{a. Pattern should be dynamic}


Parenting should be consistent with the growth and development of children. For example, the adoption of parenting for children under five is certainly different from parenting for school-aged children.

\section{b. Patterns must be in accordance with the needs and abilities of children.}

The potential of the child has begun to look like if hearing the music, he is more interested than children his age, if parents already have a picture of potential children, then he needs to be directed and facilitated.

\section{c. Mother and Father must be compact}

Father and mother should apply the same parenting pattern. In this case, both parents should "compromise" in determining the values that may and should not.

\section{d. Patterns must be accompanied by the positive behavior of parents.}

Implementation of parenting also requires positive attitudes from parents so that it can be an example/role model for their children. Embed the virtues of goodness with an easy to understand explanation.

\section{e. Effective communication}

The requirement for effective communication is to take time to talk to the child. $\mathrm{Be}$ a good listener and do not underestimate the opinion of the child.

\section{f. Discipline}

The application of discipline also becomes part of parenting, start from small and simple things. For example, cleaning up the room before leaving for school children also need to be taught to create a daily schedule so that it can more regularly and effectively manage its activities.

\section{g. Parents are consistent}

Parents can also apply consistency of attitudes, such as children should not drink cold water when being coughing, but if the child is in good health it is okay.

\subsection{Psycho-Educativeand Psycho-Religious in Parenting}

The process of teaching children in the womb can only be done by their parents, and it is impossible to be done by teachers because all the needs of children in the womb can only be understood by their parents. Consequently, developmental psychologists share a few of developmental stages either before birth or after birth so that the educational process is carried out on the intended target. In many kinds of literature it is mentioned that the process of growing a child fully, is influenced-at least-by four factors that interact with each other, that is an inorganic-biologic factor, psycho-educative, psycho-social culture and psycho-religious. The child will grow healthy if all four factors are met well. Patterns of parenting by the family, not just give advice and knowledge guidance only. But need to pay attention to physical needs of children, such as kosher and nutritious food. Because in terms of intellectual mental development, ex: level of intelligence and mental-emotionalaccording to the study of health much determined by the development of the central nervous and other physical organs.

Therefore, a mother who is in the comb with her physical and mental condition must be primed so that her baby can grow healthy and well developed [5]. In the care of children also demand parents in a prime, good attitude, methods and good personality, so that the education is given to hit the target. Child behavior, according to psycho-educative and personality is driven by the imitation process and the identification of children against the behavior of parents or their families. Because the primary and first educational process of a human being 
originated from his family. Therefore, the provision of psychological food to children will have a significant impact on the mental and moral development of children in the future. Batista (in [5]) says the most valuable inheritance parents can give to their children is a few minutes each day. Compassion, attention, education, and coaching are psychological foods that parents need to give to children, so that will give birth to a healthy generation psychologically in the reality of social life.

\section{METHOD}

\subsection{Research design}

This research uses the qualitative approach with descriptive method. While the informants of this study the parents in some of Village in North Aceh District, Aceh province, Indonesia, namely; Bungkah Village, Keude Mane Village (Muara Batu sub-district); Village of Sulu Barat Cot Murong (Dewantara Sub-district), Village of KeudeGeudong (Samudera Subdistrict), Village of Keude Paya Bakong (Paya Bakong Sub-district).

\subsection{Data Source}

The taking of data of this research by means of; (1) in-depth interview, by asking questions to informant (head of household) to get complete, deep and comprehensive information; (2) observations were conducted to map the study sites and also to analyze the behavior of the new children, and (3) documentation studies, in the form of research reports, journal entries, and other relevant information.

\subsection{Data Analysis}

The data in this study were analyzed according to the interaction model of Milles and Huberman (1994) by means three stages:

1. Reduction of data is the process of selecting and simplifying rough data arising from field notes.

2. Presentation of data is the presentation of a collection of information in the form of narrative text assisted by metrics and tables.

3. Conclusions are searching for meaning, patterns, explanations, causal paths, and propositions.

Based on the model, then the data analysis is done carefully and systematically by way of verification, cross-check and a checklist of various field notes, so that the existing data is validity tested.

\section{RESULTS AND DISCUSSION}

\subsection{Parents' Knowledge of Child Care}

To get a full review of parenting in the new educational process can be analyzed after the disclosure of parental knowledge related to the style and the way each of them educates their 
children. Related information can be described based on a several of interviews with parents from somevillages in Nort Aceh districts. One of the people of Keude Mane, MuaraBatu subdistrict of North Aceh District, him stated that: "Yes, caring for ordinary children, as well as people by providing food, clothing, affection, sending and delivering to the place of study. For my children's education is very important, so they will be smart later. Yes ... the name is also the parents. Let ..want the future of the child better than us. Although I am not high school, for me, my children do not like his father is not high school"(Interview with Abubakar [45 $\left.{ }^{\text {th }}\right]$, 14/42016, a resident at Keude Mane village, Kreung Mane, North Aceh).

This knowledge of parenting by the residents is derived from the results of study and discussion with others, as well as the results of his observations on the reality of life. Also in accordance with the meaning of the role of parents as a role modelfor the family and the demands.Furthermore, another resident in an interview with TgkSulaiman, at KeudeBungkah village, North Aceh district, he is stated that: "For me, giving a child's education is an obligation of parents, so that children know what the parents mean to them. Yes, it has been a religious command to educate our children, especially the important religious knowledge we prioritize in order to know God, know their obligations after their baliqh [Arabic term]. Public education is also important so that children are no less social, if combined religious and public education, I think children will be able to put themselves in this life well. The way we as parents also do not get bored to give understanding to them, even though they are adults, still our obligation to give good advice." (Interview, 15/4/2016).

However, parents always emphasize that children's education is an obligation of parents and all parents are determined to raise children by giving education as best they can, even though the villagers do not get a formal education commensurate with modern conditions. In the meantime, people in the interior of Aceh the eastern part of the north also has a similar view.

This is as expressed by Sabaruddin (50), that: "Educating children is not easy, but it is the obligation of parents to make children happy. I even made a kind of schedule since my son was in elementary school. The goal is that they can set the time and discipline later when you can bathe yourself and rub your own clothes. Indeed the way we educate different children yes ... I sometimes often ask the opinions of ustadz [Arabic term) and community leaders when after prayers in congregation meunasah". (Interview with Mr.Sabaruddin, 22/4/2016 at KeudePayaBakong sub-district, North Aceh, Aceh).

In the meantime, the results of interviews with residents Geudong village, North Aceh district, Aceh, related knowledge of parents about the pattern of parenting more refers to the condition of the parents' own history. This is stated by Mr.Bukhari $\left(50^{\text {th }}\right)$, as follows: "Yes, it depends on how young we are, if we still have people and the time of school still hear and obey the mash and advice that our parents taught, when we already have children also contagious. I used to be trained by my parents quite tight, my parents want me to be a successful afterlife. My parents taught me also the ethics of life, I still remember until now, that you must succeed in school and have to study religion today, yes when I am old like this can teach my children, give soft advice and teach them with my ability to make their life well in the future"(Interview with Mr.Bukhari, in KeudeGeudong, dated 23/4/2016).

The informant's experience also contributed significantly to the development of psychoeducation and psycho-religious children. Various experiences and advice and lessons that parents have can be taught to cultivate aspects of psycho-education and religious children. 


\subsection{Development of Psycho-educative and Psycho-religious Child}

Parents who become informants of this research generally know the term of general education, such as elementary to upper secondary school and religious education, such as recitation of the Qur'an in meunasah (Aceh term), mosques and wider religious knowledge in dayah or pesantren. With this review knowledge in general, the family/parents focus on the reality of parenting or providing education of children from primary school through high school to try their best in both aspects of education. Similar opinion Mr.Abubakar $\left(45^{\mathrm{th}}\right)$ resident Keude Mane,MuaraBatu sub-district, North Aceh district, Aceh, he is sad: "I am not a long school, as I know, I educate my children by giving good teachings or advice. I put my children to the study site on the night about 2 hours and also accompanied them to study, and during the school day, in order to read and write. Basically we parents must meet the needs of our children, they don't know their parents when they are developing". (Interview,14/4/201).

Another informant, in MuaraBatu District, North Aceh.TgkSulaiman $\left(48^{\text {th }}\right)$, stated that: "In educating children at home, for me, it is important education, especially religious education. If our children do not know the religion, they are sure if they grow up, do not know their parents, do not know their environment, do not know God the Creator. So as much as I can teach the science of religion, although my children also I enter into the recitation, so they are more excited again to study and study the teachings of religion. Then I send them to school as well as Islamic school (madrasah), for example, the age of 7 years, I enter into Islamic elementary school (MIN), whose brother is 14 years old school in Islamic junior high public school (MTsN). That way what is taught in the house and in the place of the studying (the Qur'an) don’t forget" (An Interview, 15/4/2016).

A similar understanding is also revealed from the habits of Mrs. Halimah $\left(48^{\text {th }}\right)$, a middleaged woman who has been a 2nd-year singles parent for her family in Cot Murong village, North Aceh, his said: "I don't know the terms of today, sir, as told in the television. I take care of my children as well as other people, give and instruct the school gently, so do I with the science of religion, besides taking them to the recitation bale to be able to recite the right and know the correct ways of worship in place my Leung. That's how to raise my kids since his dad no longer exists. Alhamdulillah, my children still hear their mother, very grateful to me, hopefully, they can continue their study later"(Interview, 20/4/2016).

Furthermore, other residents also have a parenting way that is almost similar to previous informants. Mr.Sabarudin (50), who states that: "For me, the importance of my children-I can stabilize the inner needs of happy children, such as religious education as well as adequate general education while I am still healthy and aged by God, all I do for children. Although I am not a rich person, I am very grateful to be able to send my children to college and also able to include children's fatherhood. Right day school children, a night at Qur'an recitation center (dayah, term Arabic), his name also dayah in kampong I can control. So that's how I educate children if they have college also live in dayah". (Interview, 22/4/2016 at KeudePayaBakong, North Aceh).

Description ofsomeinterview result can be interpreted that the application of education from family at home is focused on the development of psycho-educative and religion. How to educate children also begins at elementary school, in this way when children enter the early adolescence years (ABG), although there is a fight within the child can still be neutralized, so with the strong attention of the family of children aged ABG can understand he still has a family. This informant takes care of loving care and attention to every important need for the development of her child, but firmly by not allowing her children into a non-directional relationship. This results in the care that the family expects in this social reality. 


\subsection{The Parental Barriers in Parenting of Early Adolescence}

In relation to this condition, in the process of childcare does not mean there are no obstacles or obstacles faced by his parents, but quite a lot of obstacles and challenges, both driven by internal factors family and the influence of the surrounding environment. Some of obstacles in the new parenting of parents in North Aceh district, Aceh, can be seen from the following descriptions of interviews.

The experience of Kreung Mane residents, North Aceh district, Aceh-Indonesia Mr. Abubakar $\left(45^{\text {th }}\right)$ in educating his children, full of bitterness and lamented, but this person apply the patient patience always when faced with problems.

The description of the obstacle statement felt by the father of four children is: "Oh, there are so many obstacles and obstacles that I feel in raising children and teaching useful knowledge for the future of children. His name is also a villager. The obstacles we face of course the problem of the family economyis mediocre, sometimes the money for the children's snacks alone is not enough, but with promises I promise, the children also understand. Other obstacles also exist, lazy children learn because of embarrassment there is no book package, because of not enough books package, yes forced to have a potato yes. Because loads like indolent children learn. This is when indolent learning sometimes a problem for me, yes oneone way is patient ". (Interview with Mr.Abubakar, 14/4/2016, in Keude Mane village, Kreung Mane, North Aceh).

Similar views were also expressed by Mr.Sabarudin $\left(50^{\text {th }}\right)$, who works as a builder and planters in KeudePayaBakong village every day. According to him, "Yes there are many obstacles and obstacles in developing teenagers, I have two children who are in junior high school, one woman is third grade, and the new men first grade junior high, his second brother is second class high school, the eldest already studying in Banda. Sometimes I almost cry when the kids ask for money again no money at all. We are in the village, the most to the rice fields and there is also a rambutan garden patch. That's my income, but once I try to make the children able to school and also diligently study and study the science of religion. I nurse them if at home often give advice only, and also prohibit if already neglected to learn". (Interview with Mr.Sabarudin, in KeudePayaBakong village, 22/4/2016).

Furthermore, the statement submitted by Mr.Bukhari $\left(50^{\text {th }}\right)$, one of the residents of KeudeGeudong, who is a teacher of elementary school, is also not much different from the views of other residents. "Obstacles and obstacles in guiding children at home must many once, but Alhamdulillah can be controlled. I think with the way I give confidence and choice in children, they turn out to choose to go to school, studying religion in dayah or they want to be homeless. I give advice and explanation as you know, children choose a school and also to dayah, accidental dayah near home, so no need to stay out studying Qur'aniceleventh clock at home. I pray every time I pray that my children will be guided to the right path". (Interview with Mr.Bukhari, at KeudeGeudongvillage, North Aceh, 23/4/2016).

Based on the description of the interview above, it can be understood that in general the people of the village experience difficulties in educating and nurturing their children. Constraints often occur in economic terms. In addition, if the child has less motivation to learn fostered back the spirit of learning so that enjoy children return to study.

\subsection{Discussion}

Theoretically, early adolescents are identic to teenagers, were a period of transition from childhood to adulthood. This period according to psychologists is a turbulent time in order to 
stabilize maturity from the physiological, psychological and social. Usually, ateenager can be understood as anindividual who transitions from childhood to early adolescence, so that physical, psychological, social and economic conditions also change. From some psychological research reports about parenting, school children concluded there are at least two important things that must be recognized and considered parents/family at home and teachers in schools, namely the context of self-confidence and self-concept child or adolescent. WHO limits the concept of self-confidence as a behavior that makes individuals have a positive and realistic view of themselves and the situation around them [6]. Neill [7] said,self-confidence the extent to which an individual has faith in his judgment of his ability and the extent to which the individual can sense the rightness to succeed. Bandura (in Hurlock [8]) self-confident is a belief someone to be able to behave in accordance with expectations and desires. Therefore, it can be understood that self-confidence is an individual positive attitude that enables him to develop a positive assessment of himself and the environment or situation. In the meantime, self-concept is defined as all thoughts, beliefs, and beliefs that are individual knowledge of himself and affect relationships with others [9]. Calhoun \& Acocella [10] explains that there are at least three important aspects of human self-concept: knowledge, hope, and self-assessment. From the findings of this study in various research purposes can be analyzed that from parents knowledge about parenting, illustrates that in general, the people of North Aceh have adequate knowledge in nurturing or educating school-aged children, including children of early adolescence.

\section{CONCLUSION}

In general, parent of knowledge in North Aceh in newly grown children (ABG Indonesian term), has a common view, that childcare is considered an obligation for every parent to provide a complete education for the child. In addition, according to residents parenting also the command of religion, so inevitably parents should be happy to provide education to children since elementary school age with a gentle and affectionate way so that the child's emotions stable in the face of reality.

The application of parenting is more focused on fostering and empowering aspects of psycho-educative and psycho-religious since both aspects are considered as something that can balance the conditions of child development in social reality in the future. In addition, residents also understand that the aspect of general education and religion of their children is very important for future life in line with the needs of the development of the era.

In the educational process of children, every parent perceives the various obstacles. The main constraints faced by society in nurturing the early adolescents are economic problems and the child's internal condition (understood as a different child character) as an implication of the physical and psychological development of the individual. In addition, the influence of cultural environment and social change also drain the energy of parents, both in the sense of physical and psychological in the reality of childcare.

\section{References}

[1] A. K. Baihaqi, Mendidik anak dalam kandungan. Jakarta: Rajawali Grasindo Persada, 1996.

[2] G. T. Prasetya, "Pola pengasuhan ideal," Jakarta Elex Media Komputindo, 2003. 
[3] Z. Daradjat, Ilmu Jiwa Agama, XV. Jakarta: Bulan Bintang, 1996.

[4] T. S. Indira, "Pola asuh penuh cinta," 2008. [Online]. Available: http://www.polaasuhpenuhcinta.com. [Accessed: 18-Mar-2016].

[5] D. Hawari, "Ilmu kedokteran jiwa dan kesehatan jiwa," Yogyakarta Dana Bhakti Primayasa, 1999.

[6] World Health Organization, Adolescent mental health promotion: trainers' guide on dealing with emotions. WHO Regional Office for South-East Asia, 2003.

[7] J. Neill, "Definitions of Various Self Constructs: Self-esteem, self-efficacy, self-confidence \& selfconcept," Accesed http//wilderdom. com/self/on June, vol. 14, p. 2009, 2005.

[8] E. B. Hurlock, Psikologi Perkembangan: Suatu Pendekatan Sepanjang, 5th ed. Jakarta: Erlangga, 1999.

[9] G. Stuart and S. Sundeen, Buku ajar keperawatan jiwa. Jakarta: EGC, 2005.

[10] J. F. Calhoun and J. R. Acocella, "Psikologi tentang penyesuaian dan hubungan kemanusiaan," Semarang IKIP Semarang, 1995. 